\title{
Højskole i 150 år
}

\section{- bøger omkring et jubilæum}

\author{
Af Hans Henningsen
}

\section{Begyndelsen i Rødding}

Den 7. november 1844 åbnede den første danske folkehøjskole i Rødding. I jubilæumsåret 1994 har Käthe Z. S. Pedersen og John Pedersen med bogen »Rødding Højskole 1844 - 1994« ydet et værdifuldt bidrag til højskolehistorien, ikke mindst perioden i Rødding før 1864.

Rødding Højskole var mere end nogen anden skole i højskolebevægelsens første hundrede år et fors $\varnothing \mathrm{g}$ på at virkeligg $\varnothing \mathrm{re}$ de tanker, som Grundtvig havde givet udtryk for gennem sine højskoleskrifter i 1830'erne, tanker som for en væsentlig del havde deres baggrund i de politiske begivenheder i samtiden, først og fremmest indførelsen af stænderforsamlingerne.

Ingen har stærkere følt behovet for, at folkestemmen kunne få mund og mæle, end den nationale vækkelses repræsentanter i hertugdømmet, blandt dem Chr. Flor, der stod bag initiativet til oprettelsen af højskolen i Rødding, og som efter det første forvirrede halve år sikrede, at skolen kunne fortsætte, ved selv en tid at overtage ledelsen.

Af de skiftende forstandere søgte først og fremmest Sofus Høgsbro, der som den eneste fik en rimelig lang arbejdsperiode, at fastholde Flors samfundsorienterede linie. Det var en balancegang til flere sider, men Høgsbros forstandertid, fra 1850 til 1862, blev trods stridigheder og konflikter glansperioden i Rødding Højskoles omtumlede tilværelse før 1864.

Mellem de slesvigske krige bredte der sig den opfattelse, at det nationale spørgsmål var ved at være løst, og nogle mente derfor, at skolen nu måtte satse mere på det landbrugsfaglige. Det skærpede en strid, som var opstået mellem Høgsbro og skolens landbrugslærer. Men næppe var denne konflikt bragt til en løsning, før nye problemer dukkede op.

Efterhånden var nemlig koldske tanker begyndt at vinde indpas $\mathrm{i}$ Rødding, først og fremmest gennem lærer Jens Lassen Knudsen, hvis 
bror gårdejer Knud L. Knudsen fra Forballum i 1855 blev indvalgt i skolens tillidsmandsinstitution sammen med Grundtvig og Flor. Flor besluttede imidlertid straks at trække sig. Han frygtede, at en alliance mellem Grundtvig og Knudsen ville føre skolen i en anden retning, end han havde $\emptyset$ nsket. Det lykkedes dog at overtale Flor til at genindtræde $\mathrm{i}$ bestyrelsesarbejdet.

Men retningen i højskolebevægelsen var blevet en anden. Det blev i stigende grad vækkelserne, der tegnede billedet, og hvad inspirationen fra Grundtvig angår, flyttedes nu vægten bort fra det samfundsborgerlige. Jens Lassen Knudsen arbejdede for, at Rødding Højskole skulle udvikle sig til »en ren grundtvigsk institution «, hvor ingen kunne optages uden på forhånd at bekende sig til de grundtvigske synspunkter. Til sidst forlod han Rødding og rejste over til Kold i Dalum. Men forinden havde han medvirket til at gøre livet besværligt for Høgsbro, som i 1862 opsagde sin stilling for at hellige sig sit politiske arbejde. Efterfølgeren blev den unge teolog Ludvig Schrøder, der året før var kommet til Rødding som vikar, og som blev påvirket stærkt af Jens Lassen Knudsen uden dog at overtage det rabiate »grundtvig-koldske « syn.

Det viste sig i øvrigt, at Knudsen inden afrejsen havde medvirket til, at såvel forstanderens som lærernes lønninger blev nedsat, hvad især Schrøders hustru, officersdatteren Charlotte f. Wagner, skal have været mindre taknemmelig for.

Med Schrøder blev kursen lagt om i retning af det grundtvigkoldske, men hans tid i Rødding blev kort. Krigen i 1864 vendte op og ned på alting, og hverken Schrøder eller lærerne havde lyst til at fortsætte under de ændrede vilkår, men ønskede at flytte til et sted nord for den nye grænse. Dermed forsvinder Schrøder ud af Rødding Højskoles historie og fremstillingen følger ham af gode grunde ikke længere.

Men også Flor støttede Schrøder og stillede sig i spidsen for en indsamling til fordel for den nye skole i Askov, som fra 1869 endog kom til at bære hans navn: »Flors Højskole«. De forskelle i henseende til højskolesyn, som havde vist sig i Rødding, forhindrede altså ikke, at man nu kunne trække på samme hammel.

Der var dog ikke i alle kredse tilfredshed med skolens »flytning «. Samtidig med at Schrøder startede et sommerhold for piger under interimistiske forhold i Askov, åbnede Cornelius Appel på Rødding 
en pigeskole, som bestod til 1885, hvorefter skolebygningerne var ejet af frimenigheden indtil genåbningen i 1920.

I mellemtiden var højskolen i det gamle land blevet en fast etableret bestanddel af landbokulturen. Interessant er jubilæumsbogens påvisning af, at mens Rødding Højskole før 1864 kunne tiltrække unge fra flere forskellige samfundslag, rekrutterede skolen efter genåbningen i 1920 så godt som udelukkende sine elever fra landbohjem. Især i Hans Lunds forstanderperiode fra 1926 - 52 blev Rødding bondeh øjskolen fremfor nogen. Bondens livsform indgik som en integreret del af Lunds højskole- og menneskesyn. Perioden fremtræder på en vis måde som Røddings storhedstid, men vidner også om, i hvilken grad højskolen - og ikke kun Rødding - havde knyttet sig tæt til et bestemt samfundslag.

Skolens nyere historie forekommer visse steder noget summarisk behandlet i jubilæumsbogen. Først og fremmest savner man fyldigere personskildringer af de senere forstandere og de ganske mange markante lærere, som gennem årene har virket på Rødding. Men som helhed er fremstillingen værdifuld og oplysende, ikke mindst hvad det tidlige Rødding angår.

\section{Kundskab og Ånd}

Om hvordan forskellige højskoleopfattelser kunne trives side om side i praksis, skønt de var hinandens modsætninger i teorien, vidner også et andet skrift fra jubilæumsåret, »Kundskab og Ånd - Ask Højskole 1869-1994«, skrevet af kirkehistorikeren, dr. theol. Thorkild C. Lyby, som i mange år har været tilknyttet Ask højskole, som lærer og siden som formand for bestyrelsen.

Allerede før 1844 var der flere steder med st $\varnothing$ rre eller mindre held gjort fors $\emptyset \mathrm{g}$ på at oprette højskoler, ofte på en noget anden baggrund end den grundtvigske. Bogen omtaler flere eksempler. Som en udløber af oplysningstidens og enevældens reformbestræbelser var der i samfundet skabt en betydelig interesse for oplysning. Meget i den senere højskolebevægelse må ses på denne baggrund.

Efter den nationale katastrofe i 1864 skød højskoler op overalt i landet. Nogle var først og fremmest båret af bondens trang til uddannelse og social og politisk ligestilling, andre desuden af vækkelserne og det grundtvig-koldske skolesyn. 
Til den første type hører i udpræget grad de skoler, som fik navn efter grundlæggeren af Viby »højere landboskole« ved Århus, Lars Bjørnbak. En af dem var Ask Højskole, som i 1994 kunne fejre sit 125 års jubilæum som den eneste af de gamle »bjørnbakske« skoler, der har overlevet, men vel at mærke de sidste hundrede år som grundtvigsk højskole.

Om denne skoles omskiftelige historie gennem 125 år handler Thorkild Lybys bog, som også tegner et levende billede af de forskellige skoletypers sameksistens i Århusområdet i sidste halvdel af forrige århundrede. 25 højskoler fandtes her inden for en radius af 30 km. 7 består endnu.

Nogle var militant grundtvigske, andre »bjørnbakske«, altså kampskoler på den ene eller anden fløj, men de fleste kan ikke entydigt placeres i nogen af de to lejre. For dem var hovedsagen at dække landboungdommens behov for oplysning i nærmeste omegn. De havde ikke noget $\emptyset n s k e$ om at markere sig ideologisk i kampen mellem »aser« og »jætter«, sidstnævnte anført af Bjørnbak, aserne af Jens Nørregård, som i 1866 havde grundlagt Testrup Højskole med det formål at bekæmpe jætterne.

Men grundtvigianerne havde tidsånden med sig, og det kan, mener bogens forfatter, have bidraget til at fortegne billedet af Bjørnbak og hans folk ved at overbetone forskelle og nedtone, hvad der trods alt var fælles anliggender. Fremstillingen søger at yde begge parter retfærdighed og at efterprøve mytedannelserne. Det kommer der gerne, også her, spændende historieskrivning ud af.

Det traditionelle billede af bjørnbakkerne som rene materialister holder ikke. Det passer end ikke på Bjørnbak selv. Han lagde i sin undervisning vægt på både litteratur, religion og andre »unyttige « fag og brugte endog, som Kold, fortællemetoden. Og ind imellem kunne han formulere sig, så det til forveksling mindede om, hvad man kunne forvente at høre af en grundtvigianer.

Men i sin grundlæggende holdning tilhørte Bjørnbak den svundne rationalistiske epoke, hvilket naturligvis har bidraget til at stemple ham i grundtvigianernes $\varnothing j n e$. Men samtidig var han en usædvanligt stridbar natur. Han havde på et tidspunkt 22 processer kørende på en gang.

Politisk var bjørnbakkerne mere klassebevidste end grundtvigianerne. Og Bjørnbak udfoldede sig ikke kun som skolemand, men også som politisk agitator. Hans politik var aggressiv venstrepolitik. 
Det grundtvigske folkelighedsbegreb påbød en større forsigtighed i så henseende, men når det kom til stykket, havde begge fløje de samme fjender, Højre og de nationalliberale. Da 34 højskoleforstandere i 1877 undlod at søge statstilskud i protest mod den provisoriske finanslov, gik Bjørnbak helhjertet med, men ideen stammede interessant nok fra ærkerivalen Nørregaard.

Bjørnbakkernes anliggende var bondens emancipation, og dermed var deres højskolesyn snævrere end det grundtvigske. De havde et mål, som kunne nås, og i takt med bondestandens rejsning, politisk og økonomisk, nærmede man sig dette mål. Eksistensgrundlaget svandt dermed for denne højskoletype. Modsat den grundtvigske, som bag de aktuelle kampe fastholdt det universelle perspektiv, at højskolen principielt skal være en skole for hele folket og oplysningen en oplysning om hele menneskelivet.

Måske var det derfor Ask Højskoles held, at den i 1894 kunne gå over til at blive grundtvigsk. Overgangen forløb uden dramatik, hvilket igen vidner om, at fronterne i praksis ikke altid var så afgørende. Men respekten for reelle kundskaber blev bevaret, kombineret med troen på, at ånden, om den er til stede, ikke behøver at lide overlast, selv om det nyttige får, hvad der tilkommer det $\mathrm{i}$ form af forberedelseskurser og lignende, som det ofte har været tilfældet på Ask, en skole, der har haft rigeligt med genvordigheder at slås med gennem årene. Enkelte var selvskabte, men de fleste nok påført skolen af skiftende materielle og ideologiske konjunkturer.

Det havde været let at overbetone det negative i denne historie. Forfatteren underbetoner det ikke, men ser det i den større helhed af et trods alt meningsfyldt højskolearbejde, som har været udført på denne skole gennem skiftende perioder. Fremstillingen er helt igennem præget af forfatterens evne til at tegne et både realistisk og loyalt billede af mennesker, som er vidt forskellige såvel af natur som hvad holdninger angår.

\section{Udfordringer til Højskolen}

Foreningen for Folkehøjskoler valgte at markere jubelåret med udgivelsen af et værk af skolehistorikeren, professor, dr. pæd. Gunhild Nissen: »Udfordringer til Højskolen«. 
Umiddelbart kunne man måske tro, at denne bog handlede om fremtiden, om de udfordringer, højskolen står overfor. - Eller om de vanskeligheder, højskolen har overvundet gennem de 150 år. Begge synsvinkler havde været rimelige at anlægge i jubilæumsåret. Men bogen handler først og fremmest om, hvor højskolen har svigtet, nærmere bestemt den grundtvigske højskole. Det meste drejer sig om Askov. Så undertitlen »Danske folkehøjskoler 1844-1995« er mildest talt noget misvisende.

Hovedsynspunktet er, at højskolen, hvis anliggende skulle være universelt, blev hæmmet af alliancen med bondestanden og lod sig begrænse kulturelt af vækkelsernes kristeligt bestemte verdensbillede. Den evnede ikke i tide og i tilstrækkelig grad at åbne sig mod bykulturens moderne ungdom og svigtede, da demokratiseringen i 60'erne blev et spørgsmål om elevernes medindflydelse.

Men begyndelsen i 1844 var god nok. Initiativtageren bag højskolen i Rødding, Chr. Flor karakteriseres som en »renlivet « Grundtvigtilhænger, der nærmest punkt for punkt søgte at omsætte Grundtvigs ideer fra 30'rnes højskoleskrifter til praktisk virkelighed: »Flors arbejde og visionerne bag Rødding var en formidabel forlængelse af Grundtvigs fantasi - ned i de lokale strukturer...«. Som udtryk for det særligt grundtvigske fremhæves elevernes medbestemmelse gennem et »skoleråd « og den omstændighed, at skolen skulle være »konfessionsløs«. Flor ønskede ikke sit »emancipatoriske formål« modarbejdet af religiøse hensyn.

Men Flor var dog åbenbart ikke mere "grundtvigsk «, end at han kunne st $\varnothing t t e$ Schrøders mere vækkelsesprægede foretagende i Askov. Og nævnes bør det vel også, at Grundtvig på sin side aldrig opfattede højskoleinitiativet i Rødding som en virkeliggørelse af sin højskoletanke. Han fulgte Rødding med velvilje, men på afstand. Trods gentagne opfordringer besøgte han aldrig skolen, som dog frem til 1849 var den eneste af slagsen og den førende, indtil Kold i løbet af 1850 'erne fik succes med sine skoler på Fyn.

Et langt kapitel i bogen er helliget Ludvig Schrøder, højskolernes førstemand, som det i 1878 lykkedes at få omdannet Askov til udvidet højskole, efter at han behændigt havde udmanøvreret Nørregaard-fløjen, blandt andet ved at mobilisere det grundtvigske lægfolk, godt hjulpet bag kulisserne af hustruen, som i breve advarede mod tidens gudløshed og »de vantros oplysning «. Gunhild Nissen undskylder dette udslag af en tilsyneladende begrænset åndsfrihed som et 
fors $\emptyset \mathrm{g}$ på »bondefangeri« over for »den landlige kristeligt-folkelige fløj«.

Men nogen grund til at nære tvivl om ægteparret Schrøders reelle motiver er der vel egentlig ikke. Meget tyder på, at Schrøder klart havde indset, at tiden var en anden, og at tingene nu måtte gro nedefra, hvis noget skulle have bærekraft, samt at situationen i slutningen af århundredet filosofisk og videnskabsteoretisk ikke længere var den samme som forudsat i Grundtvigs højskoleskrifter fra 1830'rne. Det var ikke uden grund, at han ved indretningen af den udvidede højskole i højere grad havde Göteborg-tanken for $\varnothing j$ je end netop Sorø. Det vidner om en klar forståelse af, at det nu var om videnskabssynet, kampen skulle stå.

Man kan så med Gunhild Nissen beklage, at skolen ikke fuldtud magtede at tage denne udfordring op omkring 1890, da darwinisme og fritænkeri skabte problemer med eleverne. Med sin veludviklede sans for det skæbnetunge i specielt Askovs fejlgreb, beskriver hun det som en fallit, som for lange tider reducerede Askov til et vedhæng til bondekulturen.

»Den radikale frihedslinje«, som blev grundlagt af Flor, finder Gunhild Nissen i den følgende tid kun repræsenteret af enkeltstående skikkelser som Pontoppidan i 1880'erne og Borup samt hans efterfølgere fra 1890'erne. I det 20. århundrede fortsættes linien med Hal Kochs fors $\varnothing \mathrm{g}$ på endelig at frigøre højskolen for bondesamfundets omklamring og kulminerer med Engberg Pedersens demokratiseringsbestræbelser på Askov i årene 1968-70.

Med Krogerup begynder for Gunhild Nissen den moderne højskoles æra, karakteriseret ved en udstrakt frihed for eleverne og tro på elevernes evne til at bære et selvstændigt ansvar, den skoletype, som endelig bryder med den patriarkalske og kristeligt bornerte højskoletradition, og som derfor kan appellere til byungdommen.

Uvilkårligt må man spørge, hvor der er plads til Kaj Thaning i denne sammenhæng, eller om han i virkeligeden er udenfor. For også han ville fornyelse i højskolen. Thaning ydede med sin Grundtvigforskning, med disputatsen »Menneske først...« gennem foredrag, artikler og bøger samt med rejsningen af Båring Højskole en betydelig indsats for at gøre højskoletanken tilgængelig for andre end de traditionelt grundtvigske kredse. Det var også formålet med Asperupmøderne. De omtales af Gunhild Nissen, men falder dog mærkeligt ved siden af bogens hovedlinie, som er demokratiseringen. 
Men demokrati kan være flere ting. Gunhild Nissen omtaler et brev, Engberg-Pedersen ved starten af sin anden vinterskole modtog fra en af de »aktive « på det foregående hold: Vedkommende har nu indset, at den form for demokrati, han og andre var talsmænd for under opholdet, havde et »diktatorisk tilsnit«, den »menneskelige faktor « blev negligeret til fordel for en »idealistisk holdning «. Denne erkendelse post festum må nok betragtes som en del af det menneskelige udbytte af højskoleopholdet, kommenterer Gunhild Nissen. Altså friheden udvikler og modner, og før eller siden lærer eleverne af deres egne fejltagelser.

Men der må vel alligevel være en grænse for, hvor langt denne pædagogik kan bære. Og forudsætter den ikke, at skolen klart melder ud og giver eleverne modspil? Det var der også elever, der mente. Det samme gjorde et flertal af lærere og bestyrelsen, som til sidst så sig nødsaget til at gribe ind. Det endte som bekendt først med forstanderens og året efter med mindretalsgruppens afgang.

Gunhild Nissen tør ikke påstå, at Askov havde været »reddet «, om udfaldet var blevet et andet. Men der er ingen tvivl om, hvor sympatien ligger, og der smøres tykt på, når det udmales, hvilken katastrofe for skolen, det hele var.

Det svarer til en myte, som gamle 68'ere med flid har dyrket gennem et kvart århundrede, og som dele af den $\emptyset$ vrige højskolebevægelse også har haft en interesse $\mathrm{i}$ at opretholde, skønt kun få $\mathrm{i}$ højskoleverdenen - som Gunhild Nissen bemærker - har delt de opfattelser, som den radikaliserede fløj i Askov-striden førte i marken $\mathrm{i}$ årene 1968-71.

»Udfordringer til Højskolen« er dog også resultatet af et omfattende og redeligt forskningsarbejde. Men havde det ikke været bedre i højere grad at overlade fortolkningen til læseren selv? Forfatteren demonstrerer en noget skråsikker opfattelse af, hvad der er det ægte grundtvigske, og med den som ideologisk målestok sættes tingene på plads. Bl.a. K.E. Løgstrup kommer under mistanke for egentlig ikke at være grundtvigsk, hverken i skole- eller samfundssyn. Altså burde han måske slet ikke have været i Askov højskoles bestyrelse!

Hvad Gunhild Nissen har at sige om de samfundsmæssige forandringer og om højskolernes manglende evne eller vilje til klart at erkende såvel disse forandringer som højskolens egen traditionsbundethed, kan der ikke indvendes meget imod. Men det er problematisk heri at se den egentlige årsag til de problemer og vanskelig- 
heder, som opstod for både Askov og højskolen som helhed i 60'erne og 70'erne.

Af langt mere grundlæggende betydning var den åndelige klimaforandring, der generelt fandt sted i efterkrigstiden. Den kulminerede i 60'erne og omfattede i realiteten både "systemet « og dem, der mest indædt bekæmpede det. Virkeligheden var efterhånden skrumpet ind til samtid og samfund. Dette blev mere og mere iøjnefaldende op imod 80'erne, hvor demokratiseringsideologiens tågeslør begyndte at lette. Ikke mindst ungdommen kunne se det, og i stigende grad begyndte højskoleeleverne at spørge efter substansen: historien, naturen og de grundlæggende fænomener i menneskelivet.

Det var, som man havde været ved at glemme noget centralt i den danske oplysnings- og frihedstradition, nemlig at talen om »mening " og kampen for frihed ikke kan adskilles, uden at frigørelsen bliver tom og indholdsløs. Dette var højskolens virkelige krise omkring 1970. Den tids megen tale om frigørelse, demokrati og progressivt contra reaktionært ydede intet bidrag til overvindelsen af denne krise. Den aktuelle problemstilling i tiden tilslørede snarere, hvad der var den egentlige udfordring, og hvad der måske mere end noget andet gennem de 150 år har truet højskolen på selve dens eksistens.

I en note omtales den tyske samfundsfilosof Habermas. Gunhild Nissen tilslutter sig hans tale om »livsverden « contra "systemverden«. Når Grundtvig f. eks. siger, at det folkelige »står i modsætning til alt, hvad der med magt eller med list vil gøre et folk fremmed for sig selv«, er det så ikke udtryk for det samme?

Nej, ikke helt. Habermas tænker ligesom Grundtvig historisk om samfundet og mennesket og opfatter historien som en dannelsesproces. Men bortset fra denne - ikke uvæsentlige - lighed er hans tænkning mere abstrakt og formel. Habermas ville have svært ved helt at forstå, hvad Grundtvig virkelig mener med ordet »folk«, og ganske vist taler han om en »livsverden«, men ikke om »livsoplysning « i højskolens forstand.

Habermas gav imidlertid allerede i 60'erne udtryk for bekymring over det faktum, at der i det rationaliserede samfund tæres på "meningsressourcerne «. Han blev den tids modefilosof, men havde altså modsat mange af sine beundrere - også blik for epokens svaghed.

Men i løbet af de sidste 25 år er man i højskoleverdenen igen begyndt at tale om »livsoplysning «. Mange havde gerne set dette for 60 'er-bevidstheden håbløst forældede og umulige ord indføjet i 
formålsparagraffen i den højskolelov, som blev vedtaget i jubilæumsåret.

\section{Hal Koch og Krogerup}

Der skulle gå mere end hundrede år efter åbningen af den første danske folkehøjskole, før nogen igen gjorde et fors $\emptyset \mathrm{g}$ på.at skabe en højskole med et samfundsmæssigt sigte, som kunne minde om Grundtvigs højskolemodel. Det skete i 1946 med Hal Kochs Krogerup.

Med en moderne udtryksmåde kan man vist sige, at Grundtvigs samfundstænkning klart følger en consensus- og ikke en konfliktmodel. Skønt han fremhæver nødvendigheden af den åndelige strid for frihedens skyld - og de uforligelige grundmodsætninger i livet, er den overordnede ramme dog samtalen og den gensidige forståelse.

Med Grundloven af 1849 fik Danmark ikke bare en ny forfatning, men hele samfundet blev et andet. Det bevægede sig uafvendeligt mod konflikt. Fremtiden tilhørte partierne og de folkelige bevægelser. Tiden var ikke mere til national samling, men til kamp for parlamentarismen og bondens ret til fuld ligestilling, politisk og økonomisk. Med Rasmus Sørensen formulering: nu var det »bondetid«i Danmark.

Det var som et element i denne folkelige rejsning, knyttet tæt til bondestandens interesser og bondekulturen, højskolen fik sin politiske betydning. Dens rolle i samfundet blev, i hvert fald i første omgang, en anden, end Grundtvig havde forestillet sig. Hvad der var blevet Sor $\varnothing$-skolens skæbne i klassekampens og de folkelige bevægelsers æra, om planen var blevet realiseret i slutningen af 1840'rne, kan naturligvis ingen vide. Men ideen svarede egentlig ikke længere til den samfundsmæssige virkelighed. Man kunne også sige: tiden var endnu ikke moden.

I besættelsestiden, og ikke mindst i forlængelse af Hal Kochs arbejde inden for Dansk Ungdomssamvirke, styrkedes imidlertid bevidstheden om betydningen af national og folkelig samling, og det var da naturligt at hente inspiration netop i Grundtvigs højskoleskrifter fra 1830'rne.

Historien om Hal Koch og Krogerup er et vigtigt kapitel i højskolens nyere historie, og den er spændende fortalt i bogen »Hal Koch 
og Krogerup Højskole« skrevet af tidligere økonomiminister Poul Nyboe Andersen, som i 10 år var lærer ved skolen.

Men Krogerup blev en skuffelse for Hal Koch. I 1956 forlod han desillusioneret skolen. Hvad han havde forsøgt, nemlig at bygge den folkelige samtale og den politiske oplysning på organisationerne, viste sig at være naivt. Blandt dem, der blev opfordret til at komme til Krogerup som lærer, var den senere domprovst Jørgen Bøgh, som imidlertid valgte at blive i Askov. Han tvivlede på, at ungdomsorganisationerne virkelig, når det kom til stykket, ville sende deres folk til en højskole, hvis mål var at vække dem politisk til en selvstændig holdning over for ideologier og partiprogrammer. »Den vurdering skulle vise sig mere realistisk end vi andre dengang troede «, bemærker Nyboe Andersen. I ungdomsforeninger og - organisationer, fremfor alt de politiske, holdt tanken om betydningen af det folkelige fællesskab og begejstringen for demokratiet som samtale sig tydeligvis ikke ret længe efter besættelsen.

Snart var elevtallet fra den side så lavt, at det ikke blev registreret. Krogerup måtte i stigende grad »nøjes med « de elever, der kom »udefra«, mest fra byerne. Men eleverne viste sig - som på andre højskoler dengang - at være langt mere engageret i litteratur og eksistensspørgsmål end i talen om demokrati og social ansvarlighed.

I undervisningen fik samtalen dog en mere fremtrædende plads på det tidligere så dominerende foredrags bekostning. Og eleverne havde på Hal Kochs Krogerup en langt mere udstrakt frihed og selvbestemmelse end almindeligt på højskolerne dengang. På alle disse punkter gik Krogerup foran i en udvikling, som siden også nåede de andre skoler.

Om eleverne så virkelig fattede, hvad der egentlig var baggrunden for hele Hal Kochs højskoleengagement, det politiske indhold i hans højskolesyn, er et andet spørgsmål. Men det forstod til gengæld andre, i medarbejderkredsen og i de mange sammenhænge, hvor Hal Koch færdedes. Intet har mere end Hal Kochs virke omkring Krogerup bidraget til at omplante Grundtvigs tanke om samtalen og det folkelige fællesskab fra enevældens forudsætninger til det demokratiske samfund.

Hal Koch påvirkede en generation af danske politikere over et bredt partipolitisk spektrum, blandt dem Krogeruplærerne Nyboe Andersen og socialdemokraten K.B. Andersen, begge siden ministre i regeringer af forskellig farve, og begge tilhørende den kategori af 
politikere, som Henning Fonsmark i bogen »Historien om den danske utopi« - polemisk - betegner som »højskoledemokrater«.

Et åbent brev fra en kreds af højskolefolk i 1960 med en anklage mod Venstres daværende leder Erik Eriksen for blokpolitik og tilsidesættelse af samtalen ser Fonsmark som et typisk eksempel på Hal Kochs tvivlsomme indflydelse - og naturligvis i sidste instans Grundtvigs. Blandt initiativtagerne var Nyboe Andersen, som på et tidligt tidspunkt, da ungdomssamvirkets højskoleplaner endnu var på forberedelsesstadiet, havde peget på betydningen af, at et sådant oplysningsarbejde »kunne bidrage til at løfte enkelte livsvigtige sociale/økonomiske problemer ud af den partipolitiske debat«.

Altså tankegangen var tydeligt den, at ikke alt bør være partipolitik. Der er en politisk samtale, som er nødvendig og livsvigtig for folkestyret, men som ligger udenfor, eller før, partipolitikken.

Nyboe Andersen rejser det spørgsmål, om der ikke netop i dag, efter Berlinmurens fald, med de nye muligheder for demokratiet, som dette burde betyde, i særlig grad er brug for tanken om den folkelige samtale. Svaret er vel egentlig givet med den for tiden stærkt voksende interesse for Grundtvig og højskolen rundt om i verden.

Skal der være nogen mening i den tale, der i disse år lyder overalt, om betydningen af det etiske, må det også forudsætte den folkelig samtale. Etik kan ikke gøres til partipolitik og ikke påbydes fra oven. Tanken om såvel det folkelige som det mellemfolkelige fællesskab er i dag mere indlysende end nogensinde.

Deraf giver sig udfordringerne til højskolen i midten af 1990'erne.

\section{Litteraturliste:}

Käthe Z. S. og John Pedersen: Rødding Højskoles historie gennem 150 år i tekst og billeder. Udg. af Rødding Højskole. 120 kr. samt porto.

Thorkild C. Lyby: Kundskab og Ånd. Ask Højskole 1869-1994. Udg. af Ask Højskole 1994. 176 sider. 75 kr.

Gunhild Nissen: Udfordringer til højskolen. Foreningen for folkehøjskolers forlag 1994. $298 \mathrm{kr}$.

Poul Nyboe Andersen: Hal Koch og Krogerup Højskole. Odense Universitetsforlag 1993. 240 sider. $270 \mathrm{kr}$. 